\title{
A FRANÇA E A LIBERDADE RELIGIOSA NO ÂMBITO DA INTEGRAÇÃO SUPRANACIONAL EUROPEIA
}

\author{
Monica Teresa Costa Sousa 1 \\ Michael Lima de Jesus 2
}

\section{RESUMO}

O princípio da laicidade estatal vem assumindo diversas significâncias, sendo estas determinadas pelas características históricas e políticas de cada nação que a adota. A laicidade francesa demonstra uma certa significação mais voltada para a construção de "lugar comum" ("leigo"), quando se toma por referência o caso da proibição legal das indumentárias religiosas islâmicas, atitude que foi revisitada pelo Tribunal Europeu de Direitos Humanos. O caso torna-se um ponto referencial para apreciação da liberdade religiosa. Não somente nos paradigmas limítrofes da nação francesa, mas de seu diálogo com a supranacionalidade europeia.

PALAVRAS-CHAVE: Integração Supranacional Europeia. Laicidade Estatal. Liberdade Religiosa. Tolerância Civil. Uso do Véu.

\section{FRANCE AND RELIGIOUS FREEDOM IN SUPRANATIONAL INTEGRATION}

\begin{abstract}
The Principle of Secularism is gathering diverse meanings, determined by different historic and political features in each nation. The french laïcité has a meaning closer to the idea of "shared space" ("laïque"), when analyzing the legal ban of the use of Islamic religious garments. Which was reconsidered by the European Human Rights Court. The case is becoming the reference point in the study of religious freedom, not only in French nation, by inside the whole supranational European community.
\end{abstract}

KEY WORDS: Supranational European community. Securalism. Religious freedom. Civil tolerance. Veil wearing.

\section{INTRODUÇÃO}

\footnotetext{
1 Doutora em Direito pela Universidade Federal de Santa Catarina (USFC). Professora Associada na Universidade Federal do Maranhão (UFMA) nos cursos de graduação em Direito e pós-graduação (mestrado) em Direito e Instituições do Sistema de Justiça (PPGDir/UFMA) e Cultura e Sociedade (PGCult/UFMA). Professora Visitante na Universidade de Valencia/Espanha (Bolsa CAPES PVEX 88881.170435/2018-01). E-mail: mtcostasousa@uol.com.br

2 Mestre em Direito e Instituições do Sistema de Justiça pela Universidade Federal do Maranhão (PPGDir/CAPES/UFMA). Professor Assistente na Universidade Adventista de São Paulo (UNASP-EC), no curso de graduação em Direito. Diretor-Fundador do Instituto Valor e Verdade (CNPq). Endereço Postal: Estrada Municipal Pastor Walter Boger, S/N - Lagoa Bonita, Eng. Coelho - SP, 13448-900. E-mail: michael.lima@unasp.edu.br
} 
No contexto de sociedades plurais e multiculturais (principalmente quando estas carreguem tensões religiosas), é comum que debates da política-jurídica girem em torno de temáticas como direitos humanos, feminismo e religião, não somente nas academias humanísticas e sociais, mas vê-se que esta temática está presente na vida cotidiana, política e cultural.

Principalmente no continente europeu, a diversidade cultural transformou-se em desafio político com o passar das últimas décadas. Do que se conhece resumidamente por globalização, tem-se a difusão e compartilhamento de movimentos que enfatizam a diferença cultural, linguística e religiosa. Entretanto, no que tange a especificidade europeia, a pluralidade cultural ganha seus tons associados aos movimentos migratórios. Com o passar do tempo, em virtude de fatos históricos, bem como a ameaça tida como iminente em virtude destes, as minorias passaram a ser vistas como ameaça a estabilidade e a coesão estatal.

Para além disso, os fluxos migratórios intensificaram os desafios e os debates sobre identidade e nacionalismo, sensibilizando o diálogo acerca de liberdades fundamentais; tão tal que diante do processo de integração europeu e da acomodação dos imigrantes, a discussão sobre política e religião no espaço público tem se acentuado. A França atraiu e ainda continuar a atrair muitos imigrantes; dentre as nações do continente europeu, possui em seu território a maior comunidade muçulmana da Europa Ocidental - cerca de 7,5\% da população ${ }^{3}$.

Os imigrantes muçulmanos não formam uma população homogênea, a despeito da sua crença. Originários de ex-colônias francesas, são principalmente argelinos, marroquinos e turcos. Interessante destacar que mais da metade dos muçulmanos migrantes do país já possuem cidadania francesa e consideram-se franceses.

Tal cenário traça o multiculturalismo vivido na república francesa; uma. combinação de elementos múltiplos, que podem soar como convergentes ou divergentes, tais como política, direitos humanos, universalidade, igualdade, religião, Estado e espaços públicos. Todos esses elementos tornam a temática da liberdade religiosa, principalmente em virtude do uso do véu, um tema multifacetado e sensível, principalmente quanto analisado diante de temáticas que dialogam com o exercício dessa liberdade.

3 PEW RESEARCH CENTER. 5 facts about the Muslim population in Europe. Disponível em: <http://www.pewresearch.org/fact-tank/2016/07/19/5-facts-about-the-muslim-population-in-europe/>. Acessado no dia 19 de julho de 2016. 
Essas tensões, bem como os posicionamentos tomados em virtude deles, são sensíveis não somente para a nação francesa, em sua estrutura jurídica e política interna, mas principalmente quando esta dialoga com as organizações supranacionais, em uma análise multinível de esferas e análises da postura legal tomada.

\section{A LAICIDADE ESTATAL REVISITADA}

Em seus Códigos e Constituições, os Estados em sua maioria - se fundamentam como Estados Democráticos de Direito; porém, o que se analisa em Constituições democráticas não se aplica em sua totalidade na realidade de uma nação.

Isso não se dá pela ineficácia da lei, uma vez que as liberdades presentes pretendidas já estão estipuladas e estabelecidas, porém, ainda lhes falta efetivação, torna-se necessário se efetivar o modelo teórico estabelecido. E, sobre isso, o problema perpassa pela carência da efetiva neutralidade do Estado laico.

Desde os primórdios, a laicização de um Estado não é uma tarefa de fácil realização. Em virtude desta existe a necessidade de se enfrentar barreiras sólidas permeadas das mais distintas doses de crenças e convicções, e o que se busca é construir a neutralidade tão necessária para o equilíbrio do bom convívio e existência de um diálogo que vise o bem-estar comum.

Compreender o que de fato é um Estado laico é de importância ímpar para um olhar constitucional maturado, assim como para a construção de uma sociedade democrática. O que é tomado por um conceito distante e obscuro, deve ser compreendido em seu cerne e implicações.

A laicidade deve ser vista, portanto, não como um princípio que se oponha à liberdade religiosa; ao contrário, laicidade é a garantia, pelo Estado, da liberdade religiosa de todos os cidadãos, sem preferência por uma ou outra corrente de fé, inclusive dos não crentes, o que responde ao caro e democrático princípio constitucional da isonomia, que deve inspirar e dirigir, não somente atos estatais, mas o conduzir cotidiano dos cidadãos.

Como salientam Celso Ribeiro Bastos e Samantha Meyer-Pflug:

[...] o Estado deve manter-se absolutamente neutro. Isso implica o fato de ele não poder discriminar entre as diversas igrejas e templos existentes, quer para beneficiá-los, quer para prejudicá-los. A 
separação entre Estado e religião vem prevista no inc. I do art. 19 da Constituição de 1988, que declara ser vedado à União, aos Estados, ao Distrito Federal e aos Municípios estabelecer cultos religiosos ou igrejas, subvencioná-los, embaraçar-lhes o funcionamento ou manter com eles ou seus representantes relações de dependência ou aliança, ressalvada, na forma da lei, a colaboração de interesse público. ${ }^{4}$

Entretanto, a compreensão aplicada da laicidade não é elemento redentor para os desafios múltiplos da pluralidade de uma nação; este é somente um enunciador dos desafios presentes. Nessa esteira, é fundamental destacar que cada conquista da laicidade estatal francesa, na construção progressiva da democracia material, enuncia uma série de problemáticas que terão de ser solucionadas.

Assim, o projeto laicizador de uma sociedade preza por um conceito que vai além de uma mera tolerância em comunidade, a fraternidade social. Esta não se resume ao tolerar de um indivíduo (ou grupo minoritário) em uma sociedade - mesmo que de crença majoritária plural, mas se estende aos patamares de fraternidade entre indivíduos, que mesmo sendo radicalmente diferentes, se nivelam por equânimes.

\section{NEUTRALIDADE E DIÁLOGO}

Ao contrário do que ocorria em tempos pretéritos onde havia um regime de união entre Estado e religião, sendo esta um elemento central e legitimador da ordem social, observa-se atualmente em grande parte das sociedades ocidentais a existência de uma separação entre a esfera espiritual e a esfera temporal. Poucos são os Estado confessionais, ligados a um determinado grupo religioso, até porque a religião não tem hoje a influência e domínio que possuía no Medievo ou na Antiguidade Clássica.

Para analisar estes processos sociais e históricos de enfraquecimento da religião e de separação entre Estado e grupos religiosos que ocorrem no contexto da modernidade ocidental, lançou-se mão dos conceitos de secularização e laicidade. Entretanto, há grande confusão na utilização de tais ideias. O senso comum e parte dos cientistas sociais, historiadores e filósofos tratam ambos (secularização e laicidade) como termos sinônimos que supostamente fariam referência a um mesmo fenômeno histórico e social.

\footnotetext{
${ }^{4}$ BASTOS, Celso Ribeiro; MEYER-PFLUG, Samantha. Do direito fundamental à liberdade de consciência e de crença. Revista de Direito Constitucional e Internacional, São Paulo, n. 36, p. jul./set. 2001.
} 
Além de não ser um conceito de fácil definição, a laicidade assume proporções simetricamente amórficas, a depender das características da nação em que a mesma é construída. Por essa razão, não basta apenas que a mesma seja estudada em seu sentido abstrato, mas faz-se necessário que, a depender das características do Estado avaliado suas particularidades sejam levadas em conta para a maior maturação do estudo.

Como destaque diante da temática da laicidade estatal, desponta a obra do filósofo e historiador Fernando Catroga "Entre Deuses e Césares: secularização, laicidade e religião civil". Como informa o autor, em tons exegéticos, a expressão laicidade deriva do termo laico, leigo. Etimologicamente, laico se origina do grego primitivo laós, que significa povo ou gente do povo. De laós deriva a palavra grega laikós de onde surgiu o termo latino laicus. $\mathrm{O}$ termo laico, leigo, exprime uma oposição ao religioso, àquilo que é clerical ${ }^{5}$.

A laicidade implica a neutralidade do Estado em matéria religiosa. Esta neutralidade apresenta dois sentidos diferentes, o primeiro já destacado acima: exclusão da religião do Estado e da esfera pública. Pode-se falar, então, de neutralidade-exclusão. O segundo sentido refere-se à imparcialidade do Estado com respeito às religiões, o que resulta na necessidade do Estado em tratar com igualdade as religiões. Trata-se neste caso da neutralidade-imparcialidade. Ao mesmo tempo em que pode haver liberdade religiosa, pluralismo e tolerância sem que haja laicidade, como é o caso da Grã-Bretanha e dos países escandinavos. $^{6}$

Cada país possui um conjunto de características e circunstâncias sociais e culturais que possibilitam formas variadas e peculiares de laicidade e secularização. Desta maneira podemos falar em uma laicidade francesa, de uma laicidade norte-americana, brasileira, etc. ${ }^{7}$ Além não ser de forma alguma um processo linear ou irreversível, expressão disto é o que se deu na Espanha. Depois de um violento processo de laicização ocorrido nos anos 30 que levou a perda dos privilégios que a Igreja Católica possuía na nação espanhola, há um retorno a uma situação de confessionalidade de Estado, de monopólio religioso, com o Concordato de 1953, o qual define o catolicismo como a única verdadeira religião. ${ }^{8}$

\footnotetext{
${ }^{5}$ CATROGA, Fernando. Entre deuses e césares: secularização, laicidade e religião civil. 2. ed. Coimbra, Almedina, 2006. p. 55

${ }^{6}$ BARBIER, Maurice. Por uma definición de la laicidade francesa. Disponível em: www.libertadeslaicas.org.mx. Acesso em: 10 out. 2015.

${ }^{7}$ Ibid,.

${ }^{8}$ Com base em CATROGA, Fernando. Entre deuses e césares: secularização, laicidade e religião civil. 2. ed. Coimbra, Almedina, 2006.
} 
Em relação à Teoria Política, o liberalismo procurava desvincular o Estado de qualquer confissão religiosa. A neutralidade do Estado frente às religiões era um dos aspectos centrais na concepção do Estado laico proposto pelo liberalismo do século XIX, que se erguia contra a união entre Estado e Igreja, almejando uma absoluta liberdade para todas as religiões, inclusive, para as ideias antirreligiosas e o tratamento isonômico para todos os grupos religiosos. Carl Schmitt, concebia a neutralidade do Estado liberal do século XIX como não intervenção, desinteresse, tolerância passiva. Assim afirmava o cientista político alemão:

Em última consequência este princípio tem de conduzir a uma neutralidade geral frente a todas as concepções e a todos os problemas e a um tratamento absolutamente igual, quando então, por exemplo, o que pensa em termos religiosos não pode ser mais defendido do que o ateísta [...]. Daí se segue, além disso, liberdade absoluta para toda espécie de propaganda, tanto da religiosa quanto da antirreligiosa [...]. Esta espécie de 'Estado neutro' é o stato neutrale e agnóstico que não faz mais distinções e é relativista, o Estado sem conteúdo ou mesmo um Estado reduzido a um Minimum de conteúdo. ${ }^{9}$

O projeto de laicização estatal, caminha no sentido de que seja construída a existência de uma "koine epinoia" ${ }^{10}$, bem como possibilita o diálogo político (e tolerância social) para que haja uma construção progressiva de um Estado Democrático de Direto. Através da laicidade estatal, há possiblidade da existência de um "senso comum dos homens" ${ }^{11}$, desde que existam indivíduos que compreendam o espaço público como algo comum e neutro, para além dos limites de crenças "situacionalmente transcendentes e de um fervor singular",12.

\section{O LAICISMO FRANCÊS}

O laicismo é uma das características marcantes do Estado francês. Para além das suas peculiaridades históricas, constitui um dos grandes ícones de análises e controvérsias no cenário político-jurídico europeu. Característica que, inclusive, tem suscitado discussões para além das fronteiras desta nação.

\footnotetext{
${ }^{9}$ SCHMITT, Carl. O conceito do político. 1. ed. Petrópolis, Vozes, 1992. p, 124

${ }_{10}$ VOEGLIN, Eric. História das ideias políticas - volume 1: helenismo, Roma e cristianismo primitivo. Tradução de Mendo Castro Henrique. São Paulo: É Realizações, 2012. p, 174

${ }^{11}$ Op. Cit. P, 175

${ }^{12}$ RICOEUR, Paul. A ideologia e a utopia. Tradução de Sílvio Rosa Filho e Thiago Martins. Belo Horizonte: Autêntica Editora, 20015. p, 319,322
} 
O laicismo é fruto de uma progressão histórica, não foi introduzido abruptamente, haja vista a França outrora possuir características clericais bastante fortes, para além de suas fronteiras. A emancipação da sociedade em relação ao domínio religioso foi sendo feita progressivamente, ao longo de um processo iniciado com a Revolução Francesa.

Como característica determinante, o preâmbulo constitucional reforçou o Princípio da Igualdade em todos os âmbitos, proclamado na Declaração de 1789, instituindo-se a obrigatoriedade do ensino público gratuito e laico em todos os níveis, e estabelecendo os princípios fundamentais da República, estando entre eles o da laicidade e da liberdade de ensino e consciência, assegurados em $1905 .^{13}$

Entretanto, foi na Constituição da V República que se pacificou qualquer dúvida sobre a postura do Estado francês em relação ao Princípio da laicidade, estabelecendo-se em seu art. $2^{\circ}$ que a França constituía uma República indivisível, laica, democrática e social. ${ }^{14}$

No âmbito internacional, o Estado francês é signatário da Declaração Universal dos Direitos Humanos, de 1948, que assevera os princípios da igualdade (art. $\left.2^{\circ}\right)^{15}$, da liberdade

\footnotetext{
${ }^{13}$ FRANÇA. Preâmbulo da Constituição de 27 de outubro de 1946. Disponível em:

$<$ http://www.legifrance.gouv.fr/texteconsolide/mcebw.htm>. Acesso em 23dezembro 2016: “([...] Le peuple français [...] réaffirme solennellement les droits et leslibertés de l'homme et du citoyen consacrés par la Déclaration des droits de 1789 et les principes fondamentauxreconnus par les lois de la République. Il proclame, en outre, comme particulièrement nécessaires à notre tempsles principes politiques, économiques et sociaux ciaprès : La loi garantit à la femme, dans tous les domaines, desdroits égaux à ceux de l'homme. [...]; Nul ne peutêtre lésé, dans son travail ou son emploi, en raison de sesorigines, de ses opinions ou de ses croyances. [...] La Nation garantit l'égal accès de l'enfant et de l'adulte àl'instruction, à la formation professionnelle et à la culture. L'organisation de l'enseignement public gratuit et laïqueà tous les degrés est un devoir de l'État).

${ }^{14}$ Idem. Constituição de 4 de outubro de 1958. Disponível em:

<http://www.legifrance.gouv.fr/texteconsolide/mcebw>. Acesso em 23dezembro 2016: “Art. $2^{\circ}$ A França éuma República indivisível, laica, democrática e social. Ela assegura legalmente direitos a todos os seus

cidadãos, sem distinção de origem, de raça ou religião. Também respeita todos os credos." - tradução de Renata Vilas-Boas egrifo nosso. (Art. $2^{\circ}$. La France est une République indivisible, laïque, démocratique et sociale. Elleassure l'égalité devant la loi de tous les citoyens sans distinction d'origine, de race ou de religion. Ellerespecte toutes les croyances.). É importante ressalvar que tanto a Declaração de 1948 como o preâmbulo da Constituição de 1946 também fazem parte do preâmbulo da Constituição de 1958, reforçando os direitos e princípios estabelecidos nesses textos.

${ }^{15}$ ORGANIZAÇÃO DAS NAÇÕES UNIDAS. Declaração Universal dos Direitos Humanos. Piracicaba, São Paulo: Editora Unimep, 1998: “Art. $1^{\circ}$. Todas as pessoas nascem livres e iguais em dignidade e direitos. São dotadas de razão e consciência e devem agir em relação umas às outras com espírito de fraternidade. Art. $2^{\circ}$. Toda pessoa tem capacidade para gozar os direitos e as liberdades estabelecidas nesta Declaração, sem distinção de qualquer espécie, seja de raça, cor, sexo, língua, religião, opinião política ou de outra natureza, origem nacional ou social, riqueza, nascimento, ou qualquer outra condição. Não será tampouco feita qualquer distinção fundada na condição política, jurídica ou internacional do país ou território a que pertença uma pessoa, quer se trate de um território independente, sob tutela, sem governo próprio, quer sujeito a qualquer outra limitação de soberania." -grifo nosso.
} 
de consciência e de expressão (art. 19) ${ }^{16}$ e da liberdade religiosa (art. 18) ${ }^{17}$; o país também aderiu à Convenção Europeia dos Direitos Humanos, cujo artigo $9^{\circ}$ retoma e detalha o disposto no artigo 18 da referida Declaração. As duas normas jurídicas podem ser invocadas pelos franceses ante a Corte Europeia de Direitos Humanos.

A laicidade francesa caracteriza-se, numa primeira análise, por uma dupla recusa tanto da formação de um Estado ateístico (ao respeitar todas as religiões), como a de um Estado crente (ao estabelecer a separação entre Igreja e Estado, o ensino público laico e a não oficialização de uma religião), objetivando garantir a igualdade total dos cidadãos no tocante à matéria de crenças, além de assegurar a plena liberdade de consciência. Contudo, como característica marcante - que será em seguida analisada em ante uma facticidade citada, a laicidade francesa ganha tons de laicismo, de postura vinda de uma sociedade que repousa seus anseios no Federalismo, não em crenças religiosas, ou da possibilidade de estas se sobreporem antes suas bases.

\section{O CASO DAS INDUMENTÁRIAS RELIGIOSAS ISLÂMICAS: RELAÇÃO ENTRE FEDERALISMO E A INTEGRAÇÃO SUPRANACIONAL}

Em 11 de outubro de 2010, a França promulgou a Lei no 2010-1192, tornando a utilização da indumentária religiosa islâmica, em específico o véu islâmico, reservada à esfera privada ou templos religiosos, inclusive impondo sanções em caso de descumprimento da norma.

$\mathrm{O}$ artigo $2^{\circ}$ da lei traça contornos para o que deve ser compreendido como espaço público, discorrendo que o mesmo é exemplificado como ruas e avenidas ou quaisquer locais que tenham entrada permitida ao público em geral, assim como todo espaço que seja destinado ao serviço público, qualquer que seja este. O Parlamento, por sua vez, compreendeu que o uso deliberado do véu integral - pelas mulheres - acarretava risco para a segurança pública, além de não atenderem as exigências de uma convivência mínima em sociedade.

\footnotetext{
${ }^{16}$ Idem. "Art. 19. Toda pessoa tem direito à liberdade de opinião e expressão; este direito inclui a liberdade de, sem interferência, ter opiniões e de procurar, receber e transmitir informações e ideias por quaisquer meios e independentemente de fronteiras." - grifo nosso.

${ }^{17}$ ORGANIZAÇÃO DAS NAÇÕES UNIDAS. op. cit.: "Art.18. Toda pessoa tem direito à liberdade de pensamento, consciência e religião; este direito inclui a liberdade de mudar de religião ou crença e a liberdade de manifestar essa religião ou crença, pelo ensino, pela prática, pelo culto e pela observância, isolada ou coletivamente, em público ou em particular." - grifo nosso.
} 
Por esse motivo, as penalidades para o descumprimento da norma orbitam entre o pagamento de multa ou - em caráter de maior seriedade - a possibilidade da restrição de seus direitos, sendo viável inclusive a obrigatoriedade de aulas de cidadania. No que diz respeito aos indivíduos que, de qualquer forma, coajam outros para que desobedeçam a referida lei, quer por violência moral ou física, lhes serão aplicadas penalidades, sendo as privativas de liberdades cabíveis entre elas.

Por se tratar de uma norma por demais controversa, que - inclusive - poderia ser tomada como inconstitucional, e que acarretou numa imensa insatisfação da comunidade muçulmana francesa, Nicolas Sarkosy, então presidente francês submeteu a lei à apreciação do Conselho Constitucional Francês ${ }^{18}$, o qual - de imediato - emitiu parecer considerando a norma constitucional, fazendo antes a mesma uma consideração: não seria possível a proibição da vestimenta integral nos locais destinados ao culto islâmico, incluindo sumariamente as mesquitas.

Desta feita, Tribunal e Parlamento apresentaram entendimento uníssono de que a vestimenta completa do véu implicaria questões de risco à segurança, assim como desrespeitaria o princípio cidadão básico de convivência (ante uma sociedade plural). Contudo, o entendimento não se atentou somente as questões limítrofes de segurança e convivência; indicou que mesmo que o seu uso seja fruto da própria volição da mulher que o carrega (e não uma mera ordenação ou obrigação da religião islâmica ou de seus líderes), este termina por colocar a mulher em uma posição de sujeição e inferioridade em relação aos homens. Em virtude disso, o uso é contrário aos ideais republicanos franceses, no que concerne a igualdade de gênero.

De pronto a lei causou tensão na comunidade mulçumana na Europa, desde a manifestação de insatisfação de fiéis moderados até manifestações dos líderes extremistas da

\footnotetext{
${ }^{18}$ A França passou a adotar o julgamento de tipos judiciários. Só o Conselho Constitucional possui prerrogativa para declarar uma lei inconstitucional, com efeitos de desconstituição do ato legislativo. $\mathrm{O}$ artigo 61 , item 1 , da constituição francesa de 1.958 instituiu a lei orgânica, que é a semelhante a lei complementar brasileira. Portanto, regulamentando a Questão Prioritária de Constitucionalidade. Para Siqueira Castro, o modelo francês adota um sistema de filtros. "Significa dizer: O Conselho Constitucional não tem a capacidade de se auto convocar, para proclamar um julgamento constitucional. E também não tem o princípio da avocatória. Não pode avocar para si processos que estejam em tramitação nas instâncias ordinárias; seja na jurisdição administrativa, que tem como órgão de cúpula o Conselho de Estado da França; seja na jurisdição judicial, que tem como órgão de cúpula a Corte de Cassação", analisou. http://www.conseil-constitutionnel.fr/
} 
Al-Qaeda. Organizações como a Anistia Internacional também se manifestaram contrariamente à proibição do uso dos véus ${ }^{19}$.

Fato interessante é que nem toda a França manifestou posicionamento favorável a promulgação da referida lei. Nesse contexto, a Comissão Nacional Consultiva dos Direitos Humanos (CNCDH), antes da lei (ocorrida em 21 de janeiro de 2010) manifestou-se acerca da problemática do véu integral, demonstrando posicionamento contrário à lei. Como base axiomática, a CNCDH utilizou o princípio da laicidade estatal, discorrendo que este - tomado de forma unitária - não poderia ser princípio fundamentador de uma norma que, em prática, teria trazia tamanho contexto vexatório e estigmatizador à comunidade muçulmana francesa.

No que diz respeito às mulheres, a Comissão se mostrou temerosa de que as mulheres islâmicas, no exercício de sua fé sejam privadas do acesso às vias públicas e à escola, possibilidade que é tomada como ininteligível. A Comissão sugere ainda, diante do multiculturalismo existente em território francês, uma política pública que seja embasada na defesa e incentivo do diálogo intercultural, tendo em vista que a rigidez da lei promulgada cooperaria para uma polarização cultural A CNCDH trouxe ainda a atenção acerca da importância de uma educação que seja voltada para a disseminação formativa de valores como os de cidadania e direitos humanos ${ }^{20}$.

Thomas Hammarberg, Comissário de Direitos Humanos do Conselho da Europa, demonstrou também contrariedade à proibição da $\operatorname{burca}^{21}$ e do $n i q a b^{22}$ pelo Estado francês, em 7 de março de 2010, sob a motivação de que tal norma é por demais invasiva a privacidade dos muçulmanos ${ }^{23}$. Hammarberg compreende que o continente europeu deve estar atento a respeito da crescente aversão ao islamismo, além de encarar a proibição do véu como uma atitude que terminará por agravar a desigualdade de gênero, tendo em vista que as

\footnotetext{
${ }^{19}$ MORAES, Anderson Júnior Leal; FONSECA, Mariana Martins de Castilho. A Vivência da diversidade republicana dentro da escola e o fracasso da política de integração cultural francesa. Revista da Faculdade de Direito da UFMG, Belo Horizonte. No. 56. P. 44. Jan./Junho de 2010.

${ }^{20} \mathrm{http}: / /$ hudoc.echr.coe.int/sites/eng/pages/search.aspx?i=001-145466\#\{"itemid":["001-145466"]\}

${ }^{21}$ Vestimenta que cobre todo o corpo da mulher, acrescido de uma malha a cobrir-lhe os olhos. A burca propriamente dita, em algumas regiões também conhecida como chadri, é uma veste que cobre todo o corpo, com uma rede diante dos olhos para permitir a visão. No Afeganistão era de uso obrigatório durante o regime do grupo extremista Talibã. Hoje não é mais obrigatória, mas ainda usada por mulheres que temem pela sua segurança caso não o façam, principalmente em áreas rurais. A burca também é muito comum no Paquistão, principalmente em territórios da etnia pachto.

${ }^{22}$ Vestimenta que cobre todo o rosto da mulher, com uma abertura apenas para os olhos. O niqab é muito usado na Arábia Saudita, no Iêmen, no Omã e nos Emirados Árabes Unidos. Ele é um véu propriamente dito, cobrindo o rosto e o pescoço, com apenas uma abertura diante dos olhos. O niqab costuma ser usado sobre uma outra vestimenta de corpo inteiro, daí a confusão com a burca.

${ }^{23} \mathrm{http}: / /$ tgeu.org/tag/thomas-hammarberg/
} 
mulheres muçulmanas seriam impossibilitadas de frequentar a escola trajando a vestimenta religiosa e nem poderiam transitar em espaços públicos.

Tendo em vista os artigos $8^{\circ}$ e $9^{\circ}$ da Convenção Europeia de Direitos Humanos $\mathrm{CEDH}$, o Comissário pondera que a lei se opõe diante dos referidos artigos. O cerne não se fundamenta na concordância ou discordância da indumentária religiosa islâmica; o mesmo acredita ainda que a imposição de véus seja uma medida profundamente repressiva e inaceitável, ao mesmo tempo que pondera que o problema não será solucionado com atitudes que possam ser tomadas como discriminatórias, mas com respeito e diálogo entre cultural heterogêneas $^{24}$. O Comissário de Direitos Humanos ainda explica que pluralismo, multiculturalismo e o respeito pela diversidade são valores que devem ser amplamente discutidos e exercidos na Europa.

Uma cidadã francesa, de origem franco-paquistanesa e pertencente à religião mulçumana, que preferiu ocultar seu nome ao ser denominada S.A.S, recorreu ao Tribunal Europeu dos Direitos Humanos, alegando que os artigos $8^{\circ}, 9^{\circ}$ e $14^{\circ}$ da Convenção Europeia dos Direitos Humanos foram violados pelo governo francês, pois considerava que a referida lei afrontava o seu direito de liberdade religiosa e de expressão.

S.A.S. tornou claro o fato de não ser pertencente a nenhuma ramificação radical da religião mulçumana, e que a mesma fazia uso da burca e do hijab de forma esporádica, em datas religiosas como o Ramadã, em virtude de sua grande devoção a sua religião. Ela tornou claro que não sofre nenhuma pressão por parte dos homens da família para que se vista dessa maneira. Para além de todo o exposto, deixou claro que nunca se negou a colaborar em aeroportos e alfândegas, onde é necessária a retirada do véu por razões de segurança ${ }^{25}$.

Através de suas alegações no processo nº 43835/11, o Estado francês, não escondeu o fato - perante o Tribunal Europeu - que a referida lei carrega consigo o valor intrínseco de limitar liberdades de muçulmanos. Entretanto, alegou que a mesma se faz necessária para que sejam preservados os ideais e perenidade de uma sociedade democrática, bem como os objetivos republicanos da nação francesa. Citando o mesmo aporte já utilizado, como o da proteção da segurança pública, tendo em mente que o véu dificulta a identificação necessária de qualquer indivíduo; a preocupação com a promoção da igualdade de gênero e da dignidade humana e, por fim, o estabelecimento de regras mínimas de convivência social.

\footnotetext{
${ }^{24}$ http://g1.globo.com/Noticias/Mundo/0,,MUL1519421-5602,00 COMISSARIO+DE+DIREITOS +HUMANOS+DA+EUROPA+CRITICA+PROIBICAO+DE+BURCA.html

${ }^{25}$ http://hudoc.echr.coe.int/sites/eng/pages/search.aspx?i=001-145466\#\{"itemid":["001-145466"]\}
} 
O Tribunal de Direitos Humanos, ao examinar o caso n. 43835/11, o fez mediante exaustiva análise de temas como a prática e a legislação doméstica; a prática e a legislação internacional e a situação em outros países europeus; para, em ato contínuo, conhecer do pedido formulado. Com vistas em sua jurisprudência, a Corte reiterou que a enumeração de exceções para as manifestações de direitos individuais ou de crenças é exaustiva e suas definições são restritivas, sendo necessário que as limitações às mesmas estejam em linha com objetivos legítimos.

No que tange a segurança pública, de acordo com o Tribunal, a fundamentação primeira será legítima a declarar a licitude da norma francesa. Em uma interpretação conectiva também reconheceu a legalidade do banimento daquelas vestimentas em público no caso da busca de proteção dos direitos e liberdade de terceiros e na manutenção da ordem pública, sendo os dois últimos argumentos acolhidos com ênfase. Em alguns casos já havia decidido que interesses individuais devem ocasionalmente se subordinar ao de um grupo. Para além disso, asseverou que a legislação em exame se justificava pela garantia do convívio em sociedade.

O Tribunal Europeu proferiu sua sentença em 1 de julho de 2014. O Estado francês foi tomado como autônomo para legislar da peculiar questão supracitada, mesmo que o sentido semântico de tal atitude se ponha em contrariedade aos dispositivos basilares da Convenção Europeia, como o artigo $8^{\circ}$ e $9^{\circ}$, sob o esteio do princípio da laicidade. Compreendeu que o governo francês entende o uso do véu como uma vivência dissonante dos valores republicanos franceses, sendo este o motivo para a sua proibição. A Corte alega que a demanda do Estado tem por finalidade o estímulo de uma maior interação entre os indivíduos, o que, em sua opinião, é requisito indispensável para a expressão do pluralismo, não só, como também, de tolerância ${ }^{26}$.

Em casos como relativa similitude a este, o TEDH inclina-se a ser ponderado ao exercer restrições ao fiel cumprimento da $\mathrm{CEDH}$, uma vez que essa avaliação permite notar que o equilíbrio foi atingido através de um processo democrático realizado no foro íntimo da

\footnotetext{
${ }^{26} \mathrm{http} / /$ hudoc.echr.coe.int/sites/eng/pages/search.aspx?i=001145466\#\{“itemid”:[“001-145466”]\}

"However, for their part, the Government indicated that it was a question of responding to a practice that the State deemed incompatible, in French society, with the ground rules of social communication and more broadly the requirements of "living together". From that perspective, the respondent State is seeking to protect a principle of interaction between individuals, which in its view is essential for the expression not only of pluralism, but also of tolerance and broadmindedness without which there is no democratic society (see paragraph 128 above). It can thus be said that the question whether or not it should be permitted to wear the fullface veil in public places constitutes a choice of society".
} 
sociedade francesa. Sob tal linha de pensamento, a lei esvaziou as possibilidades legais da sua formalidade. Além de ter sido aprovada pelo Parlamento francês, foi referendada pelo Conselho Constitucional. Para além de tal questão, na observação de questões com palpáveis similitudes, o próprio TEDH observa, em matéria de política geral deve ser dada à política interna um peso especial.

A decisão possuiu caráter heterogêneo; os juízes Nussberger e Jaderblom discordaram dos demais magistrados e justificaram seus motivos na sentença. Ambos se posicionaram contrários à decisão do TEDH que, segundo eles, sacrificou direitos importantes, como a garantia à sua própria identidade cultural e religiosa, garantidos pelos $\operatorname{artigos} 8^{\circ}$ e $9^{\circ}$, da Convenção.

Ambos endossaram que o respeito pela igualdade entre homens e mulheres e o princípio da dignidade humana não justificam por si só a proibição da ocultação da face em lugares públicos. Concordam que é necessário haver a identificação das pessoas, até mesmo para sua própria proteção, mas que essa identificação poderia ser considerada em um contexto em que a segurança pública possa ser ameaçada, como acontece em aeroportos e bancos. Acreditam que os temores e sentimentos de mal-estar não são tantos causados pelo próprio véu, mas pela filosofia que se presume estar ligada a ele, a crença da subserviência feminina ${ }^{27}$. O convencimento a essas mulheres a interagirem e participarem ativamente da vida social ao "estilo francês", é uma questão individual e resta a cada uma delas decidir, não passa pela mera questão de uso do véu ou não. Não cabe ao Estado intervir nesses tipos de assuntos da esfera privada. $\mathrm{O}$ artigo $9^{\circ}$ da $\mathrm{CEDH}^{28}$ torna claro que todo cidadão possuiu o direito de manifestar sua religião, e a utilização de acessórios que identifiquem essa crença faz parte desse direito. Os véus, crucifixos, turbantes e tantos outros, fazem parte dessa manifestação religiosa expressando respeito e submissão à religião escolhida. A proibição tem, como alvo, um código de vestimenta intimamente ligada à fé religiosa, da cultura e

\footnotetext{
${ }^{27}$ http://hudoc.echr.coe.int/sites/eng/pages/search.aspx?i=001-145466\#\{"itemid":["001-145466"]\}

"It seems to us, however, that such fears and feelings of uneasiness are not so much caused by the veil itself, which - unlike perhaps certain other dress-codes - cannot be perceived as aggressive per se, but by the philosophy that is presumed to be linked to it.".

${ }^{28}$ ARTIGO $9^{\circ}$ Liberdade de pensamento, de consciência e de religião 1. Qualquer pessoa tem direito à liberdade de pensamento, de consciência e de religião; este direito implica a liberdade de mudar de religião ou de crença, assim como a liberdade de manifestar a sua religião ou a sua crença, individual ou coletivamente, em público e em privado, por meio do culto, do ensino, de práticas e da celebração de ritos.

2. A liberdade de manifestar a sua religião ou convicções, individual ou coletivamente, não pode ser objeto de outras restrições senão as que, previstas na lei, constituírem disposições necessárias, numa sociedade democrática, à segurança pública, à proteção da ordem, da saúde e moral públicas, ou à proteção dos direitos e liberdades de outrem.
} 
convicções pessoais e, portanto, sem dúvida, um direito íntimo relacionado com uma personalidade.

Não só os juízes citados concordaram que, no caso do julgamento referido, houve violação ao artigo $8^{\circ}$ e $9^{\circ}$ da Convenção, como também o Comissário para os Direitos Humanos e as organizações não governamentais ${ }^{29}$. Todos se opuseram veementemente a qualquer forma de proibição ao uso do véu. A discussão toma por esteio o questionamento se o Estado francês tem o direito de proibir que essas mulheres usem suas indumentárias religiosas.

\section{CONSIDERAÇÕES FINAIS}

O caso do laicismo francês, faz ponderar sobre as questões limítrofes da laicidade estatal, bem como o seu propósito basilar, qual seja a neutralidade, o diálogo e a tolerância entre os heterogêneos. Um dos axiomas de uma sociedade democrática e plural deve ser o de o Estado pautar suas ações buscando fundamento na democracia, na submissão aos direitos humanos, na secularização e na autonomia do homem.

Diante da pluralidade, heterogeneidade e multiculturalismo, deve existir tolerância, esse é o sentimento (ou a busca construtiva) que deve permear na convivência de sociedades que onde a diversidade múltipla se encontra presente no mesmo território. É de fundamental importância compreender que não é suficiente a neutralidade de um Estado ante as questões religiosas, ou a mera proteção da pluralidade (ou o assegurar desta). É de fundamental importância compreender que tolerância, ou para além disso, a solidariedade (que repousa em um ideal de fraternidade francês), não brota de um Direito meramente posto, mas do diálogo e interação ${ }^{30}$.

O TEDH se fundamenta no argumento da neutralidade do Estado invocado pelas autoridades nacionais para sustentar a proibição do uso do véu. O princípio do secularismo, fundamento que anda de mãos dados com o a neutralidade, apesar de não se encontrar previsto na $\mathrm{CEDH}$ como um dos fins legítimos para a restrição do direito à liberdade religiosa, é considerado pelo TEDH, que parece tomar partido por uma perspectiva secular

\footnotetext{
${ }^{29}$ http://hudoc.echr.coe.int/sites/eng/pages/search.aspx?i=001-145466\#\{"itemid":["001145466"]\}.

${ }^{30}$ HABERMAS, Jürgen. Entre naturalismo e religião: estudos filosóficos. Tradução Flávio Beno Siebeneichler, Rio de Janeiro: Tempo Brasileiro, 2007, p. 9.
} 
ao confirmara sua importância nos Estados que o invocam e, em razão desse argumento, anuir que as medidas restritivas implementadas prosseguem fins legítimos numa sociedade democrática.

A França é a nação que compreende povo como laós. O termo não somente é a origem etimológica da laicidade estatal, como também define a semântica sociopolítica que é empregada no que tange a convivência social. Laós é um relativo grego para a palavra hebraica Goy, utilizada para denominar os pagãos. Pagãos, ou gentílicos, precisamente por não terem parte espiritual com a aliança com entre a divindade e um pouco escolhido, eleito.

Ao mesmo tempo que o termo polis era empregado para caracterizar uma realidade social de notória manifestação política, ao indicar uma comunidade que, organizadamente e como iguais, vivia junta, mas sob um vínculo civil e jurídico, isto é, como uma cidade-estado. Laos é o povo que constitui tal cidade. Laós originou a expressão laikós, de onde surge a expressão latina laicus e, em português, leigo e laico, comum.

A laicidade é permeada pela convicção de que as tarefas e desafios humanos devem ser resolvidos no tempo histórico, com e através do próprio tempo histórico, além de levar em consideração e serem dirimidos pelo "homem comum" - o homem leigo. As individualidades dos indivíduos, até mesmo suas crenças, não são suprimidas. Compreende-se, somente, que o espaço público (bem como seus argumentos e indivíduos) é “comum”.

O indicativo de ser comum o espaço público, assim como os indivíduos que o habitam, rememora a noção de republicana. O termo res publica significa literalmente "a coisa pública" e designa uma noção tanto jurídica quanto política. Envolve uma organização institucional determinada por regras de direito, pela solidariedade e união dos cidadãos em uma comunidade; é a expressão política do povo em seu conjunto (populus).

Exatamente por se tratar ser necessária a devida neutralidade para que haja o convívio (e construção) política no meio social, é necessário que haja a "koine epinoia" ${ }^{31}$ de uma sociedade, sua coisa comum. Disto posto, não há coisa comum quando do espaço público é ausente "senso comum dos homens" ${ }^{32}$, senso que está fundamentado além dos limites de crenças "situacionalmente transcendentes e de um fervor singular" 33. Partindo de tal fundamentação Tribunal Europeu dos Direitos do Homem (TEDH) considerou legítima a

\footnotetext{
${ }^{31}$ VOEGLIN, Eric. História das ideias políticas - volume 1: helenismo, Roma e cristianismo primitivo. Tradução de Mendo Castro Henrique. São Paulo: É Realizações, 2012. p, 174

${ }^{32}$ Op. Cit. P, 175

${ }^{33}$ RICOEUR, Paul. A ideologia e a utopia. Tradução de Sílvio Rosa Filho e Thiago Martins. Belo Horizonte: Autêntica Editora, 20015. p, 319,322
} 
proibição do uso do véu integral em França, rejeitando assim o pedido que reivindicava o direito a usar o niqab ou a burka.

\section{REFERÊNCIAS}

BOBBIO, Norberto. A era dos direitos. São Paulo. Campus, 1990.

A era dos direitos. Tradução Carlos Nelson Coutinho. Nova edição. Rio de Janeiro: Elsevier, 2004.

Teoria geral da política: a filosofia política e as lições dos clássicos. Tradução

Daniela Beccacia Versiani. 29. ed. Rio de Janeiro: Elsevier, 2000.

Cultura laica y laicismo. 1999. Jornal El Mundo, Espanha. Disponível em: http://www.elmundo.es/1999/11/17/opinion . Acesso em: 01 novembro de 2015.

BONAVIDES, Paulo. Teoria geral do Estado. 8. ed. São Paulo: Malheiros, 2010.

CATROGA, Fernando. Entre deuses e césares: secularização, laicidade e religião civil. 2. ed. Coimbra, Almedina, 2006.

CIFUENTES, Rafael Llano. Relações entre a Igreja e o Estado. 2 ed. Rio de Janeiro, José Olympio, 1989.

DHAL, Robert. A preface to democracy theory. Chicago: University of Chicago Press, 1956. 
JOVER, Adoración Castro Jover. Laicidad y actividad positiva de los poderes públicos.

Revista general de Derecho Canônico y Derecho Eclesiástico, España, nº 3, octubre, 2003. Disponível em: www.olir.it . Acesso em: 20 jan. 2007.

HABERMAS, Jürgen. Religion in the public shere. European Journal of Philosophy 14, Cambridge, Polity, (2206): 1-25

A inclusão do outro: estudos de teoria política. São Paulo: Edições Loyola, 2002.

. Era das transições. Rio de Janeiro. Tempo Brasileiro, 2003.

.Entre naturalismo e religião: estudos filosóficos. Tradução Flávio Beno

Siebeneichler, Rio de Janeiro: Tempo Brasileiro, 2007

HIMMELFARB, Gertrude. Os caminhos para a modernidade: os iluminismos britânico, francês e americano. São Paulo: É Realizações Editora, 2011.

MIRANDA, Pontes de. Democracia, liberdade, igualdade: os três caminhos. Campinas: Bookseller, 2002.

MORAES, Anderson Júnior Leal; FONSECA, Mariana Martins de Castilho. A Vivência da diversidade republicana dentro da escola e o fracasso da política de integração cultural francesa. Revista da Faculdade de Direito da UFMG, Belo Horizonte. Nº. 56. P. 44. Jan./Junho de 2010.

SARMENTO, Daniel. A ponderação de interesses na Constituição Federal. Rio de Janeiro: Lumen Juris, 2002. Júris, 2010.

Livres e iguais: estudos de direitos constitucional. Rio de Janeiro: Editora Lumem

RICOEUR, Paul. A ideologia e a utopia. Tradução de Sílvio Rosa Filho e Thiago Martins. Belo Horizonte: Autêntica Editora, 20015. p, 319,322

SOWELL, Thomas. Os intelectuais e a sociedade. São Paulo: É Realizações Editora, 2011.

VOEGLIN, Eric. História das ideias políticas - volume 1: helenismo, Roma e cristianismo primitivo. Tradução de Mendo Castro Henrique. São Paulo: É Realizações, 2012. p, 174 